\title{
Buried with turtles: the symbolic role of the Euphrates soft-shelled turtle (Rafetus euphraticus) in Mesopotamia
}

Rémi Berthon ${ }^{1,2}$, Yilmaz S. Erdal ${ }^{3}$, Marjan Mashkour ${ }^{1}$ \& Gülriz Kozbe ${ }^{4}$

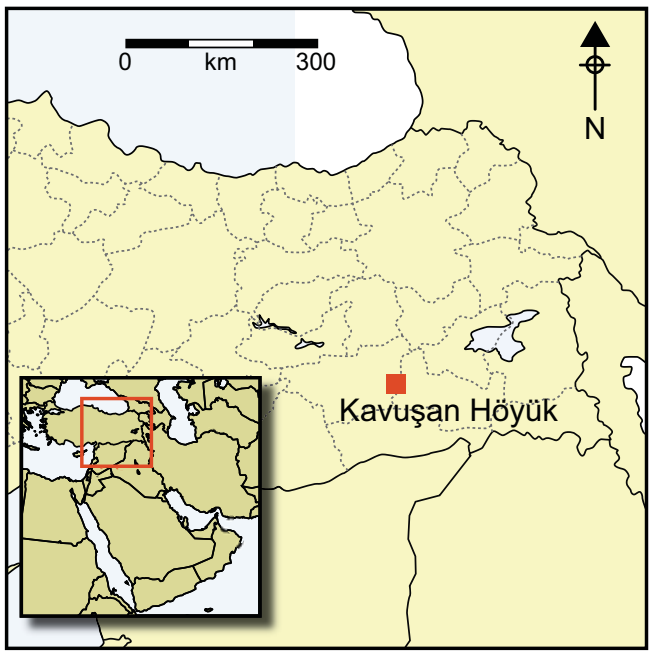

Excavations at Kavuşan Höyük (southeastern Turkey) have revealed evidence of the use of turtles, tortoises and terrapins in postAssyrian funerary practices. Of particular significance are the remains of the Euphrates soft-shelled turtle (Rafetus euphraticus), distinguished from other species of turtle by their quantity and treatment in the burial pit under investigation here. The unique finds from Kavuşan Höyük, coupled with archaeological and textual records, underline the economic and symbolic significance of these animals for communities in prehistoric and early historical Mesopotamia.

Keywords: Mesopotamia, Kavuşan Höyük, post-Assyrian, Euphrates soft-shelled turtle, chelonian

\section{Introduction}

The relationship between human societies and the wild animals living in and around their settlements has always been mediated by a mixture of economic interest, ritual and religious beliefs. For ancient societies, the nature of this relationship is not always immediately apparent from the available bioarchaeological evidence, material culture or writings. This is particularly the case for that of the inhabitants of prehistoric and early historical Mesopotamia and the Euphrates soft-shelled turtle (Rafetus euphraticus), and indeed other

1 Archéozoologie, archéobotanique: sociétés, pratiques et environnements (UMR 7209), Sorbonne Universités, Muséum national d'Histoire naturelle, CNRS, CP56-55 rue Buffon, 75005 Paris, France (Email: rberthon@mnhn.fr)

2 Archéorient-Environnements et sociétés de l'Orient ancient (UMR 5133), CNRS, Université Lyon 2, MSH Maison de l'Orient et de la Méditerranée-Jean Pouilloux, 7 rue Raulin, 69365 Lyon cedex 7, France

3 Department of Anthropology, Faculty of Letters, Hacettepe University, 06800 Beytepe, Ankara, Turkey

4 Department of Art History, Faculty of Letters and Sciences, Batman University, 72100 Batman, Turkey 
species of chelonians. Due to its reclusive behaviour and somewhat limited geographical distribution, the Euphrates soft-shelled turtle has received relatively little attention from the scientific community. There is not much information regarding the biology and behaviour of this species, and there have been no previous studies aimed at understanding the relationship between the turtle and the ancient human societies of Mesopotamia.

Remains of the Euphrates soft-shelled turtle have recently been discovered within a burial pit at the site of Kavuşan Höyük in the Upper Tigris River Valley (south-eastern Turkey). This is the largest deposit known from the archaeological record, and has led us to consider the symbolic and economic significance of this species for past societies. The assemblage of turtle remains at Kavuşan Höyük provides a basis from which to review other occurrences that have been noted in the archaeological and written records. Finally, we highlight the unique significance of the Kavuşan Höyük deposit with regard to Mesopotamia during the fourth to first millennia BC.

\section{Taxonomic remarks}

The scientific name of the Euphrates soft-shelled turtle has been given in various different forms (Fritz \& Havaš 2007: 320). The correct name, as currently agreed upon, is Rafetus euphraticus, but Trionyx euphraticus has also been widely used throughout the archaeological literature. The Euphrates soft-shelled turtle is endemic to the Euphrates and Tigris Rivers and their tributaries, and is therefore encountered in Turkey, Syria, Iraq and Iran (Kinzelbach 1986; Stadtlander 1992; Ghaffari et al. 2008). It should not be mistaken for the Nile softshelled turtle (Trionyxtriunguis), whose ancient and current distribution is restricted to the coasts of the Eastern Mediterranean (Kinzelbach 1986; Corsini-Foka \& Masseti 2008; Çakırlar 2009a \& b).

The Euphrates soft-shelled turtle is relatively large compared to other freshwater turtles of the Near East; the carapace length of mature specimens ranges from between 32 and $68 \mathrm{~cm}$ (Taşkavak 1998). The species is characterised by an olive-green leathery skin that covers its carapace (Figure 1). Although they feed on plants and vegetables, these turtles are primarily known as having a carnivorous diet. They are also scavengers and have frequently been observed feeding on the drifting carcasses of various mammals, which can be as large as a horse (Ainsworth 1888; Taşkavak \& Atatür 1998). It might be for this reason that the species is renowned for its aggression and voracity (Layard 1853). The turtle usually prefers shallower, slow-flowing waters, which are warmer than the deeper, fast-flowing stretches of river (Taşkavak \& Atatür 1998; Ghaffari et al. 2008). In the summer, groups of turtles can be observed basking in the sun in small tributaries and on the banks of the main rivers. Although there is almost no information concerning population dynamics or territoriality, it is worth mentioning that Taşkavak and Atatür were able to observe as many as 35 different individual turtles in a single day near the city of Diyarbakır (Taşkavak \& Atatür 1998: tab. 1). Fine-grained, sandy banks are the preferred location for nesting (Ghaffari et al. 2008; Biricik \& Turğa 2011). Such conditions are readily found in the Upper Tigris Valley (Biricik \& Turğ 2011), and we believe that this was also the case in the past.

ㅇ Antiquity Publications Ltd, 2016 


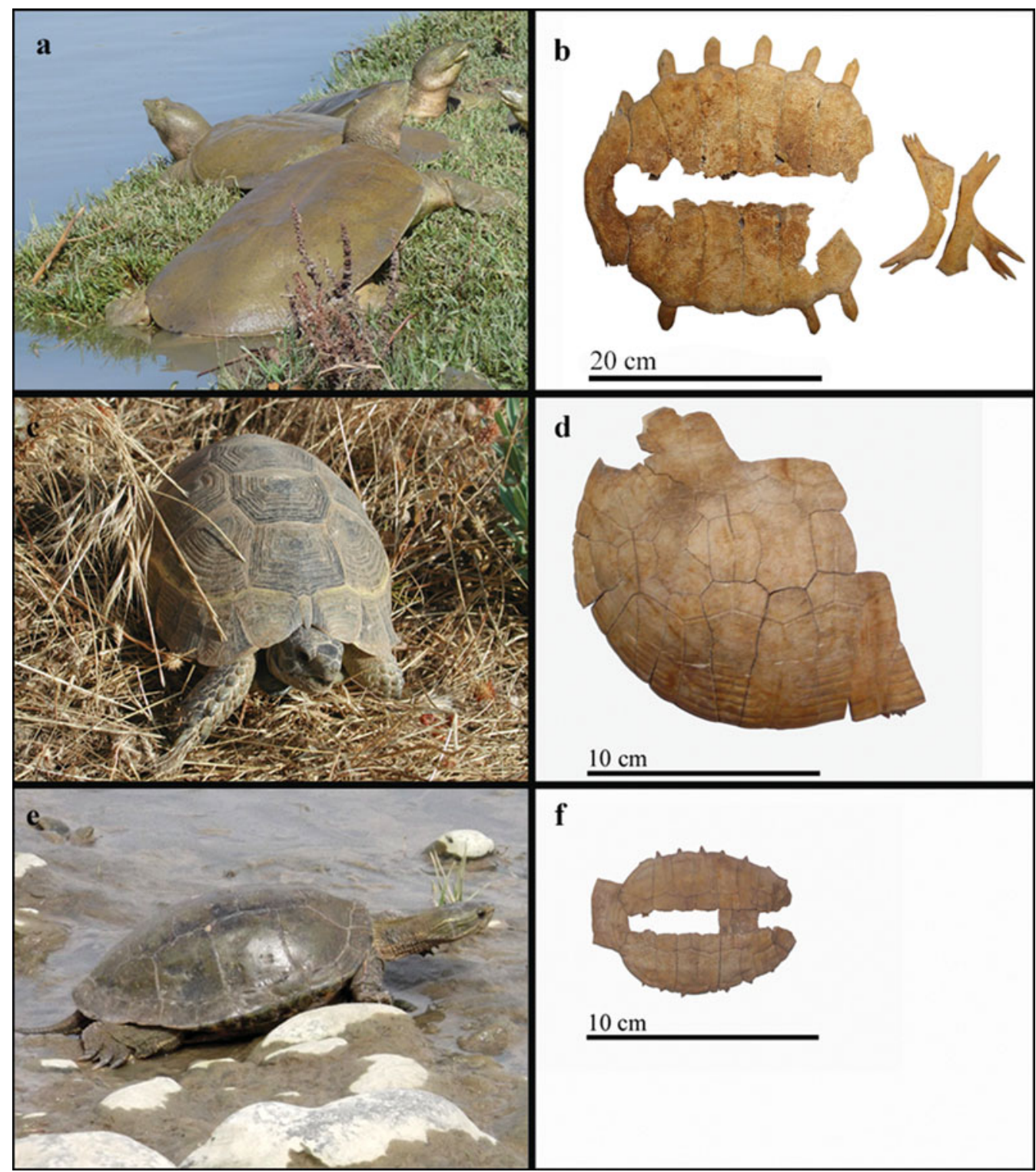

Figure 1. a) Euphrates soft-shelled turtle (Rafetus euphraticus) basking on the shore of the Tigris River (courtesy ofŞ. Turğa); b) carapace of Rafetus euphraticus from Kavuşan Höyük (dorsal view); c) spur-thighed tortoise (Testudo graeca) specimen from the Upper Tigris River area (R. Berthon); d) carapace fragment of Testudo graeca from Kavuşan Höyük (dorsal view); e) Middle Eastern terrapin (Mauremys caspica) specimen from Bismil district (courtesy of D. Ayaz); f) carapace of Mauremys caspica from Kavuşan Höyük (sub-adult specimen, dorsal view).

\section{The Euphrates soft-shelled turtles at Kavuşan Höyük}

The site and the grave

Kavuşan Höyük is a multi-period mound site located on the southern bank of the Tigris River, immediately east of the confluence with its tributary, the Şeyhan Çay (Figure 2),

(C) Antiquity Publications Ltd, 2016 


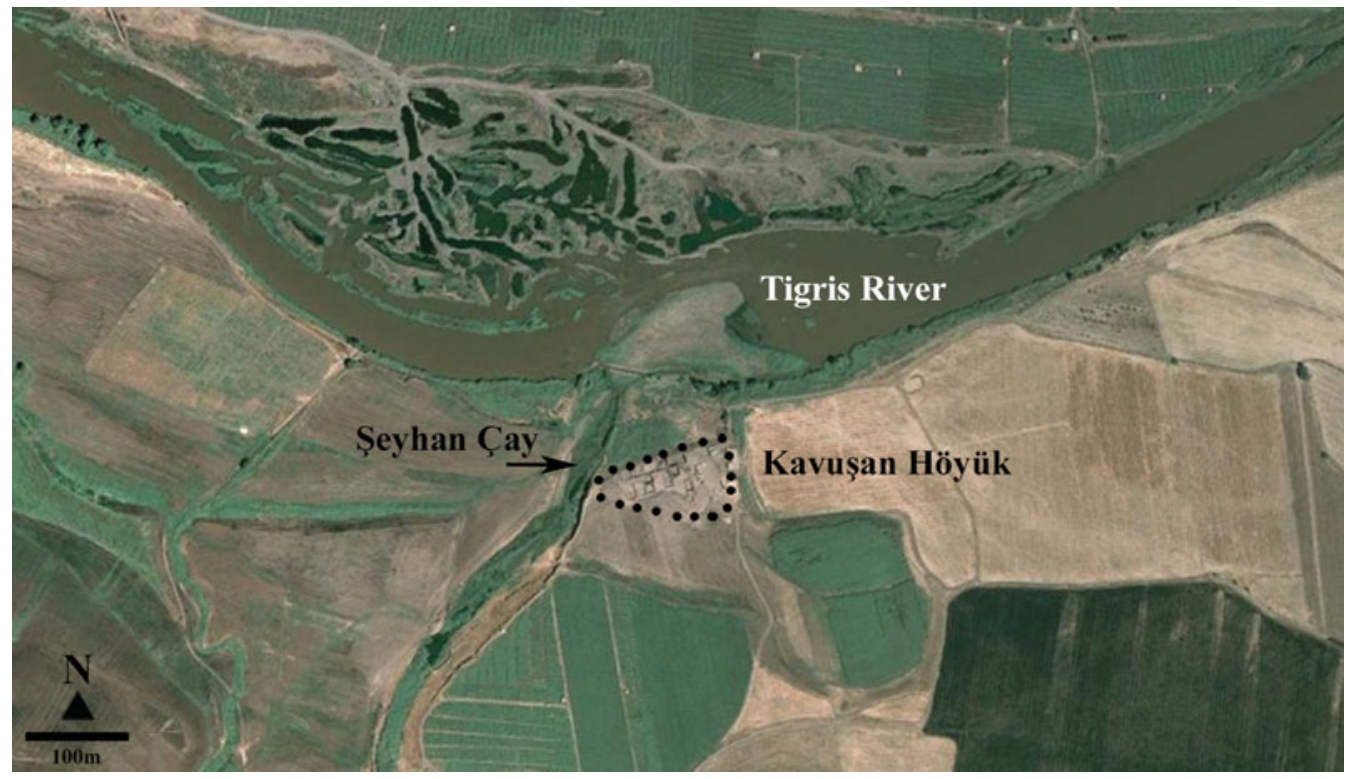

Figure 2. Location of Kavuşan Höyük (latitude 37.8255', longitude $40.7165^{\circ}$ ), on the southern bank of the Tigris River, east of the confluence with the Şeyhan Çay (base imagery from Google Earth, Digital Globe).

and approximately $10 \mathrm{~km}$ downstream from the modern town of Bismil in the Diyarbakır Province (Turkey). The site covers an area of approximately 1.5ha (Kozbe 2012, 2013). Kavuşan Höyük was excavated between 2001 and 2009, under the direction of the Directorate of the Diyarbakır Museum, and in accordance with G. Kozbe's scientific responsibilities within the framework of the Ilısu Dam and HEP Project. The archaeological excavations revealed eight occupation levels spanning from the last quarter of the third millennium BC to the fourteenth century AD, with two hiatuses in occupation (Kozbe 2013).

The burial discussed here was discovered in level IV and dated to the late Iron Age (from the late seventh century BC to the final quarter of the fourth century BC), which is known locally as the post-Assyrian period in the Upper Tigris region (Kozbe 2012, 2013). During the 2008 excavations at Kavuşan Höyük, three pits were identified in trench G11 (Figure 3). They were cut into a post-Assyrian, beaten-mud floor. A $35 \mathrm{~mm}$-long cylindrical seal, discovered on the same floor, is dated to the seventh or sixth century BC, which is consistent with the dating of the level and also provides a specific date for the pits. When the pits were excavated, it was understood that they were, in fact, elaborately dug silos. Silo 1 is approximately $1.7 \mathrm{~m}$ deep and has a cereal storage capacity of more than $800 \mathrm{~kg}$. The archaeobotanical remains and intact vessels recovered from silo 1 hint at the importance and function of this post-Assyrian feature (Kozbe 2010, 2013). Silo 2 is about $0.75 \mathrm{~m}$ deep with a cereal storage capacity of $330 \mathrm{~kg}$. Silo 3 is the largest of the three silos with a depth of more than $2.3 \mathrm{~m}$; its cereal storage capacity is estimated to be between three and four tonnes.

Two skeletons, belonging to a woman and a 6-7-year-old child, along with 21 turtle specimens, were discovered at the bottom of silo 3 (Kozbe 2010, 2013). This silo, which is pear-shaped in profile, acted as a burial pit after its original use as a storage facility. The

(C) Antiquity Publications Ltd, 2016 


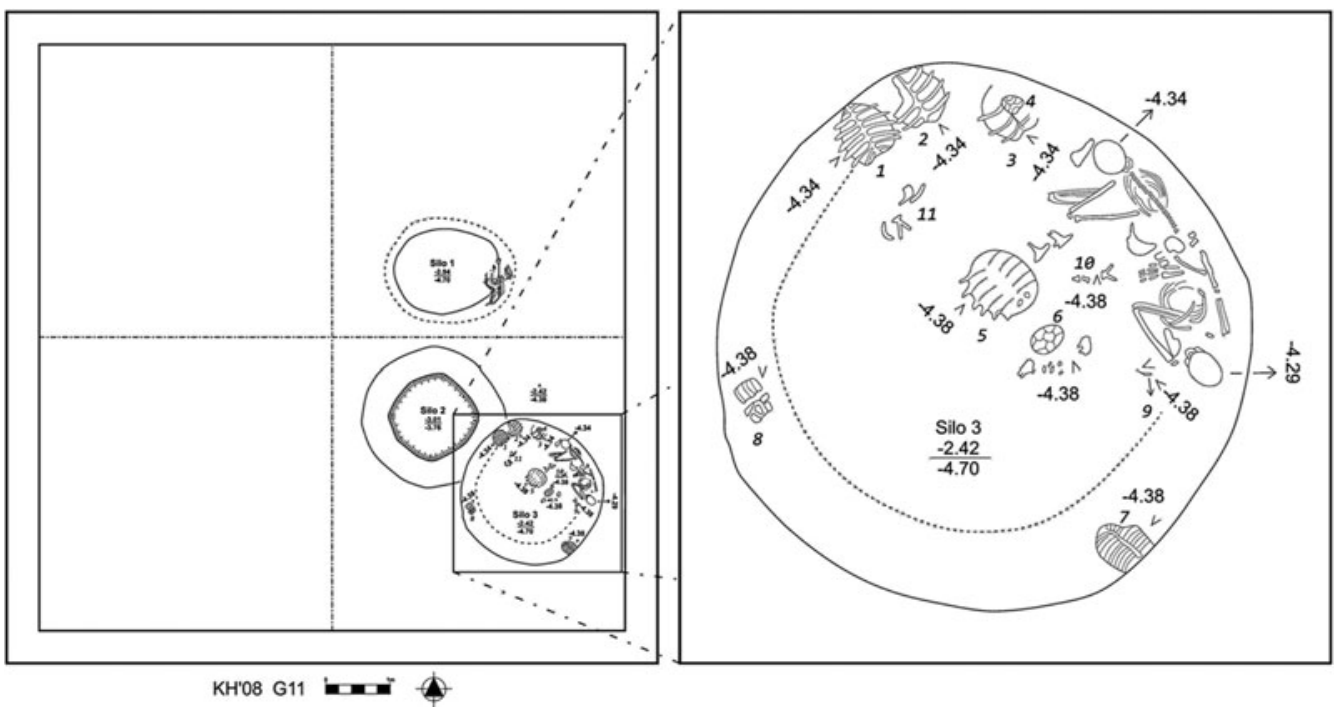

Figure 3. Position of the three post-Assyrian silos discovered in trench $G 11$ at Kavuşan Höyük (left); position of the human and chelonian skeletons in silo 3 (right); images courtesy of the Kavuşan Höyük archaeological project.

skeleton of the child was found lying face down, oriented north-south (atlas-sacrum) near the bottom of the silo and alongside the wall of the pit. Its left leg was bent at the knee while the right leg was fully extended. The right arm lies under the body, and the left is stretched above the shoulder, as if protecting the face. As secondary sex characteristics had not developed by the time of the individual's death, we have no clear evidence for their sex. A broken iron fibula grave good that was placed next to the skull may, however, indicate that the child was a girl. The child's age was determined through the examination of dental calcification (Buikstra \& Ubelaker 1994). The remains are well preserved and do not show any evidence of skeletal pathology except for slightly developed anaemia and severe dental wear on the deciduous teeth.

The adult individual was apparently buried in a semi-flexed position directly beneath the child. The skeleton was found at the base of the silo and immediately next to its wall, oriented north-south (atlas-sacrum), and facing slightly north-west. The individual was laid on their back with the left arm bent from the elbow and the hand placed on the chest, and with the right arm bent from the elbow and placed on the abdomen. A bronze anklet was found in situ around the right ankle. According to the morphological features of the cranium, mandible, pelvic girdle and other skeletal elements, the individual was a female with a gracile skeletal morphology (Acsádi \& Nemeskéri 1970; Buikstra \& Ubelaker 1994). Indicators of age such as cranial suture closure, sternal rib tips, the pubic symphysis and the auricular surfaces of the ilium (Buikstra \& Ubelaker 1994) suggest that she might have been between 45 and 55 years old when she died. No pathological conditions were observed on the deceased except for severe dental wear on the anterior dentition and periapical abscesses. No injuries or marks indicative of a cause of death were identified for either of the individuals. 


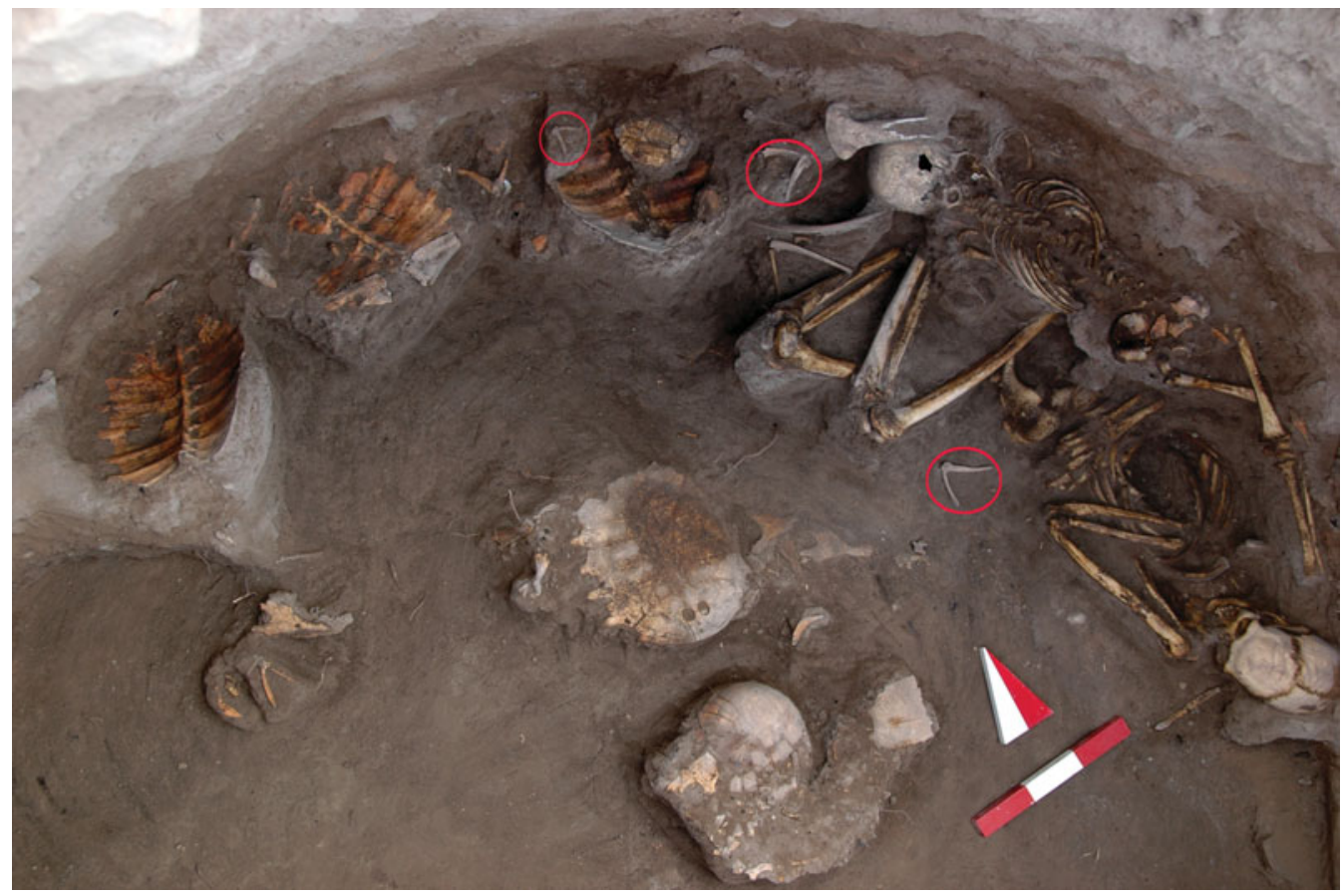

Figure 4. Photograph of the human and chelonian skeletons in situ; the red circles indicate the position of the shoulder bones of the Euphrates soft-shelled turtles (courtesy of the Kavuşan Höyük archaeological project).

Only two burial features were discovered in the post-Assyrian level at Kavuşan Höyük, the other one being a cremation urn (Kozbe 2010).

\section{The turtle and tortoise assemblage}

Most of the turtles were recovered from around the edge of silo 3, although two carapaces and some scattered skeletal elements were found in the centre of the grave (Figures $3 \&$ 4). One of these centrally deposited shells belonged to a spur-thighed tortoise (Testudo graeca), while the other remains were of Euphrates soft-shelled turtles (Figures $3 \& 4$ ). It is also interesting to note that the $\mathrm{V}$-shaped shoulder bones (scapula and acromion) of the turtles were ostensibly placed within the burial. As recently as 40 years ago in south-eastern Turkey, these skeletal elements were regularly hung around the necks or shoulders of infants to protect them against the 'evil eye' (Kozbe \& Erdal in press). The turtles are believed to have been deposited within the grave as part of some offering. Due to the scattered nature of the skeletal elements, the minimum number of Euphrates soft-shelled turtles was estimated using the most frequently found skeletal element, in this case the nuchal plate: a single element of the carapace. Seventeen nuchal plates have been discovered in the grave. Sixteen of them belonged to adults, while the seventeenth, judging by its smaller size, probably belonged to a younger specimen. Although most of the carapace elements of these specimens have been recovered, more than half of the plastron elements are missing,

(C) Antiquity Publications Ltd, 2016 


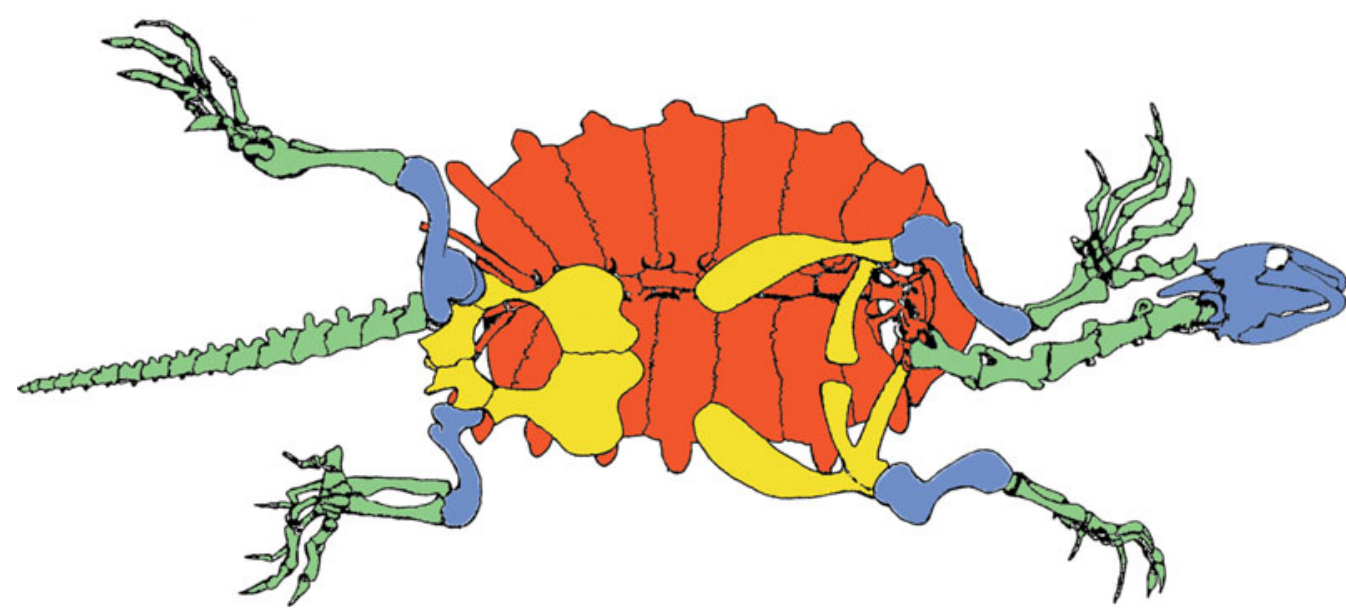

Figure 5. Proportional representation of skeletal elements for the Euphrates soft-shelled turtle in Kavuşan Höyük based on 17 specimens; green: less than 15 per cent; blue: 15-25 per cent; yellow: 26-50 per cent; red: over 50 per cent; plastron (not shown): 39 per cent.

suggesting that the turtles were butchered and opened. Other skeletal elements are also less well represented, and were probably intentionally removed as part of this process (Figure 5).

In addition to the Euphrates soft-shelled turtles, the offering also included a spur-thighed tortoise, represented by a plastron and a carapace, and three Middle Eastern terrapins (Mauremys caspica), of which there were two adults and one younger specimen, represented only by elements of the plastron and carapace. Although the Middle Eastern terrapin is very common in eastern Turkey (Vamberger et al. 2013), the findings from Kavuşan Höyük represent the first evidence of its use as a grave good. It should be noted that the tortoise and terrapins are not represented by any skeletal remains other than the carapace and plastron. Cut marks are also absent on the plastron and carapace of these specimens. Unlike the Euphrates soft-shelled turtles, the tortoise and terrapins were seemingly neither butchered nor consumed during the funerary rituals, only their empty carapaces were used as grave goods.

\section{Human processing of the turtles}

The Euphrates soft-shelled turtles that were placed in the grave were clearly butchered. Cut marks are located on 2 of the carapaces, 3 of the plastrons and 24 bones. The pectoral and pelvic girdles bear most of the cut marks (Figures $6 \& 7$ ). Cut marks on the plastron and ventral side of the ribs indicate that the turtles were turned on their backs and then cut open. In the Euphrates soft-shelled turtle, the plastron is not fused with the carapace. It is, therefore, easier to butcher a turtle by first cutting along its flanks. The cut marks and representation of different skeletal elements suggest that the meat was taken away along with at least parts of the limbs. Most of the skulls and neck vertebrae were also removed. If the turtles were cooked, this probably took place after butchering, as none of the remains from the grave show any traces of burning or other heat treatment. 


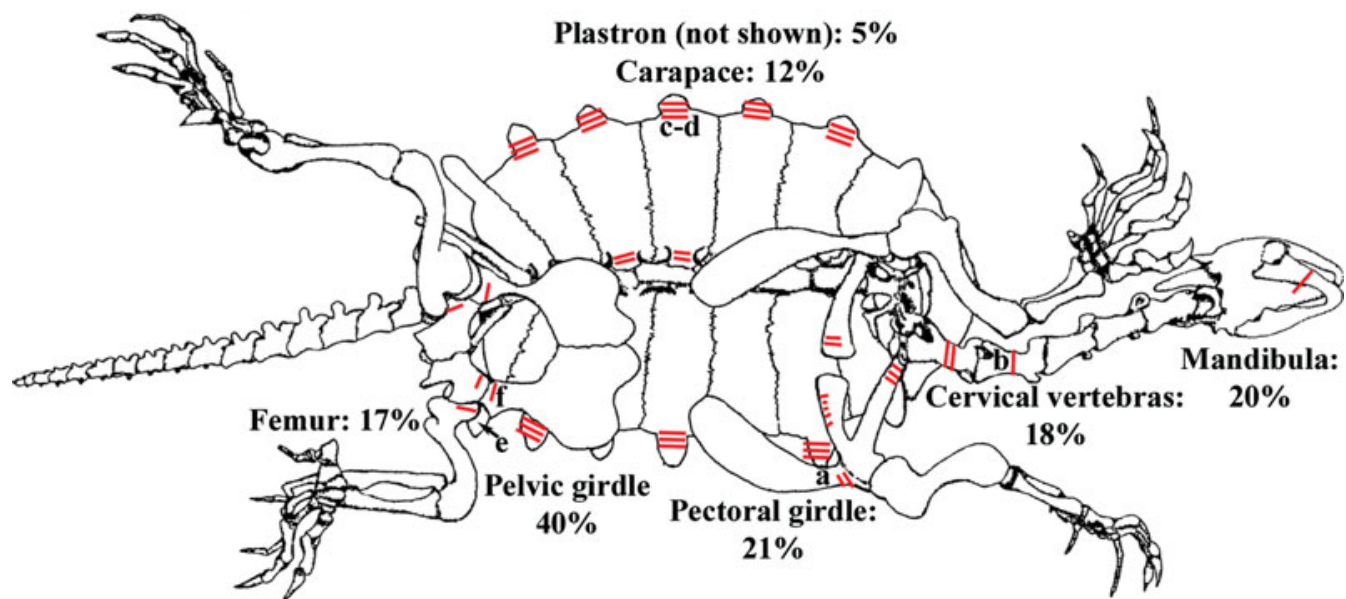

Figure 6. Location of cut marks on a Euphrates soft-shelled turtle skeleton (ventral view); relative proportion of skeletal remains bearing cut marks in percentages according to the number of remains of each element; letters indicate the position of elements shown on Figure 7.

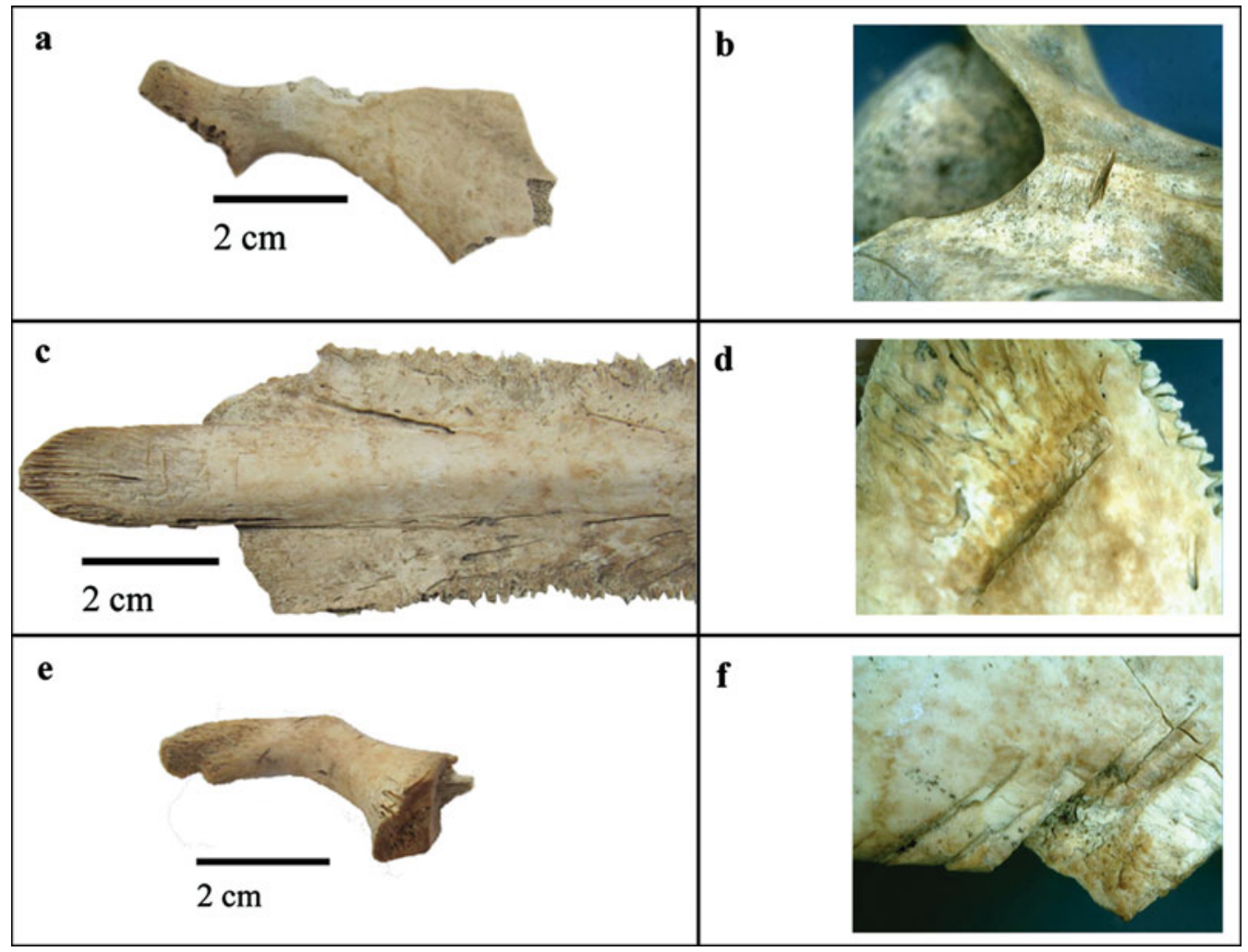

Figure 7. Photographs of Euphrates soft-shelled turtle remains bearing cut and 'hack' marks: a) left coracoid; b) cervical vertebra; c) pectoral plaque and rib; d) distal part of rib cut off the pectoral plaque; e) ilium; f) hack marks on pubic bone.

(C) Antiquity Publications Ltd, 2016 
That there are 17 turtles in the grave suggests that there would have been a sizeable population of turtles in the area. Groups of up to 50 turtles may be observed on the river banks today (M. Biricik pers. comm.). Consequently, it is not too difficult to imagine that 17 turtles could have been taken over the course of a single day for the purpose of a funerary ritual. The turtles were almost certainly collected at a very short distance from the site. As already mentioned, the location of Kavuşan Höyük is well suited for locating the Euphrates soft-shelled turtle, situated at the confluence of the Tigris River and its tributary, the Şeyhan Çay. The disposal of the village's refuse in the river would have also attracted these scavenging animals, and it is probable that the inhabitants were familiar with the turtles. We may assume that they were not captured during the winter, as it is almost impossible to observe Euphrates soft-shelled turtles from November to March in the Upper Tigris Basin.

\section{Interactions between humans and Euphrates soft-shelled turtles}

\section{Zooarchaeological evidence}

The distribution of the archaeological remains of the Euphrates soft-shelled turtle matches that of the current population. All instances of their remains come from sites located close to the Euphrates and Tigris Rivers and their tributaries (Figure 8). The frequency of remains

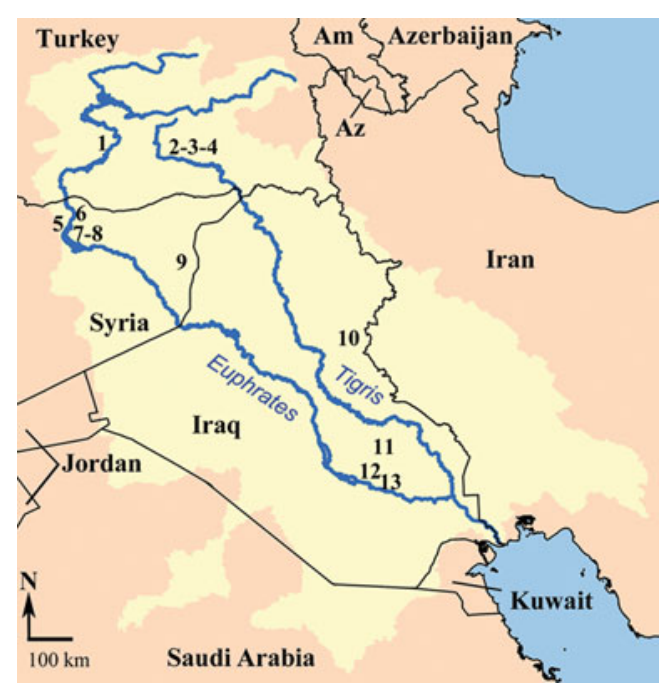

Figure 8. Location of the archaeological sites that yielded Euphrates soft-shelled turtle remains; the numbers refer to Table 1; the area in yellow corresponds to the drainage basin of the Euphrates and Tigris Rivers; Am = Armenia, Az= Azerbaijan. from Euphrates soft-shelled turtles in the zooarchaeological record is, however, conspicuously low (Table 1). The species did not play a significant role in Mesopotamian subsistence strategies from the fourth to the first millennia BC. When the number of turtle remains in the archaeological assemblage is particularly low, it is generally believed that they were unintentionally caught in fishing nets (Boessneck \& von den Driesch 1986: 153). Besides the finds from Kavuşan Höyük, clear evidence for the butchering of Euphrates soft-shelled turtles has only been recorded for one other specimen from an elite residential context at Tall Seh Hamad (Becker 1991: 126; 2008: 112). Consequently, the lack of evidence for economic exploitation of the Euphrates soft-shelled turtle emphasises the symbolic significance of its presence in the grave at Kavuşan Höyük. At this site, only two remains belonging to Euphrates soft-shelled turtles were identified from a total assemblage of over 1500 faunal elements recovered from domestic contexts (Berthon 2011). The consumption of their meat appears to have been exclusively related to funerary rituals and feasting. 


\begin{tabular}{|c|c|c|c|c|}
\hline$\#$ & Site & No. remains & Period & Reference \\
\hline \multicolumn{5}{|c|}{ Turkey } \\
\hline 1 & Hassek Höyük & $(1)[2]$ & Third millennium BC. & Stahl 1989: 154; Boessneck 1992a: 70. \\
\hline \multirow[t]{2}{*}{2} & Kavuşan Höyük & $(1)[1]$ & Second half of the second millennium BC. & Berthon 2013: tab. 2. \\
\hline & & $(368)[148]$ & First half of the first millennium BC. & This study. \\
\hline 3 & Kenan Tepe & (1) & First half of the second millennium BC. & Berthon 2013: tab. 2. \\
\hline 4 & Hirbemerdon Tepe & (1) & Second half of the second millennium BC. & Berthon pers. comm. \\
\hline \multicolumn{5}{|c|}{ Syria } \\
\hline \multirow[t]{3}{*}{5} & Habuba Kabira & 1 & Second half of the fourth millennium BC. & von den Driesch 1993: tab. 1. \\
\hline & & 6 & Third millennium BC. & von den Driesch 1993: tab. 1. \\
\hline & & 5 & First half of the second millennium BC. & von den Driesch 1993: tab. 1. \\
\hline 6 & Tell Kosak Shamali & (1) & $\begin{array}{l}\text { Second half of the fifth to the first half of } \\
\text { the fourth millennia BC. }\end{array}$ & $\begin{array}{l}\text { Gourichon \& Helmer 2003: 275; Gourichon pers. } \\
\text { comm. }\end{array}$ \\
\hline 7 & Tell Halawa & [3] & Third millennium BC. & Boessneck \& von den Driesch 1989: 140. \\
\hline 8 & Tell Munbaqa & (1) & Second half of the second millennium BC. & Boessneck \& von den Driesch 1986: 153. \\
\hline \multirow[t]{2}{*}{9} & Tall Seh Hamad & 119 & Second half of the second millennium BC. & Becker 2008: 111-12. \\
\hline & & 34 & First half of the first millennium BC. & Becker 2008: 111-12. \\
\hline \multicolumn{5}{|c|}{ Iraq } \\
\hline 10 & Tell Rubeidheh & [1] & Second half of the fourth millennium BC. & Payne 1988: 109. \\
\hline 11 & Nippur & [1] & First half of the second millennium $\mathrm{BC}$. & Boessneck 1978: 162. \\
\hline \multirow[t]{3}{*}{12} & Isin-Isan Bahriyat & $(4)[2]$ & First half of the second millennium BC. & $\begin{array}{l}\text { Boessneck 1977: 127-28; Boessneck \& Ziegler 1987: } \\
\text { 145; Boessneck \& von den Driesch 1992: } 178 .\end{array}$ \\
\hline & & (2) & Second half of the second millennium BC. & Boessneck \& Kokabi 1981: 149. \\
\hline & & (3) & Mid-first millennium BC. & Boessneck \& Kokabi 1981: 149. \\
\hline 13 & Uruk-Warqa & (1) & Third century $\mathrm{BC}$ to the third century AD. & Boessneck 1992b: 269. \\
\hline
\end{tabular}

The first column refers to the numbers on the map; for the number of remains, the numbers between ( ) refer to carapace or plastron elements, while the numbers between [ ] refer to other skeletal elements. 


\section{The Euphrates soft-shelled turtle in ancient texts and material culture}

The Babylonian word raqqu has been translated as a name for the Euphrates soft-shelled turtle (Peterson 2007: 202; Weszeli 2009) that appears in several texts and is listed among offerings for funerary and religious festivals. This species was used in medicinal and ritual practices, and was also mentioned in omens (Reiner \& Roth 1999: 172-73). The Sumerian literary composition 'Ninurta and the turtle' describes a Euphrates soft-shelled turtle with some precision (Alster 1972). The text recounts a struggle between the god Enki and the hero Ninurta. Enki fashions a turtle from mud and puts it in the water. The turtle bites Ninurta on the ankle and digs a pit with its claws into which the hero falls. This text clearly emphasises the aggressive, biting nature of the turtle, as well as its ability to dig into the soil. Other texts mention figurines crafted in the shape of the turtle. These statuettes, made from precious metal or stone, were offered to the gods as part of various rituals (Weszeli 2009: 180). No such object has yet been discovered during archaeological excavations.

\section{Economic significance}

Unambiguous evidence of turtle meat consumption is scarce. Contemporary inhabitants of south-eastern Turkey, and Arabs from the middle Euphrates area, both state that they do not consume turtle meat (Olivier 1807: 325-26; Taşkavak \& Atatür 1998: 28). Arabs, however, are known to have used the fat of the Euphrates soft-shelled turtle for treating skin diseases (Olivier 1807: 325-26). The turtle is sometimes available at fish markets (Krupp \& Schneider 1991: 73; M. Mashkour pers. comm. in Baghdad in 2002), making it probable that the meat is at least consumed on occasion. In southeastern Turkey, both the Euphrates soft-shelled turtle and the spur-thighed tortoise were consumed until at least relatively recently as a cure for various diseases (Kozbe \& Erdal in press).

\section{The symbolic role of chelonians in the Near East}

Tortoise consumption was common in the Near East from the Middle Palaeolithic up until the very late Epi-Palaeolithic (Stiner et al. 2000, 2014; Starkovich \& Stiner 2009). From the Neolithic onwards, the remains of chelonians are frequently found among Mesopotamian faunal assemblages. Despite admittedly limited evidence for tortoise consumption in Iran and Turkmenistan (S. Bailon \& M. Mashkour pers. comm.), and few texts documenting the hunting of turtles and terrapins in southern Mesopotamia (Owen 1981), chelonians appear to have played an insignificant role in diets since the Neolithic. Thus, the exploitation of turtles and tortoises was primarily motivated by the symbolic value attributed to them. This explains why, in historic documents, they are most often mentioned either as offerings or as elements of medicinal practices (Weszeli 2009). The archaeological evidence from Kavuşan Höyük suggests that they may also have played a significant role in some funerary practices. In the eleventh millennium BC, at the site of Hilazon Tachtit, in Israel, the remains of an elderly woman were buried with more than 50 spur-thighed tortoises. The woman is believed to have been some sort of shaman. The plastrons were broken in order 
to remove the tortoises from their shells, potentially for consumption as part of a feast (Grosman et al. 2008: 17667). At Körtik Tepe, a Neolithic site located a few kilometres east of Kavuşan Höyük, 16 graves were uncovered containing spur-thighed tortoise shells laid nearby or covering the heads of the deceased (Coşkun et al. 2010; Özkaya \& Coşkun 2011).

South of Mesopotamia, eastern Arabia offers striking examples of sea turtles used in funerary practices. At the fourth-millennium BC cemetery of Ra's al Hamra 5, in Oman, green sea turtles (Chelonia mydas) are often found in association with grave deposits (Salvatori 1996). A turtle skull is either placed near the face of the dead or the grave is covered with a sea turtle carapace. Twelve turtle skulls have also been recovered from a pit beside one of the graves (Méry \& Charpentier 2009: 19-20). In Anatolia today, as well as in the past, chelonians, and particularly tortoises, are used in apotropaic rituals rather than as food or for medicinal purposes. Their remains are commonly hung in houses, cars and on cradles, or they are crafted into amulets. During an ethnographic survey conducted in 2010 by G. Kozbe and Y.S. Erdal, several instances of this practice were recorded in the Bismil/Diyarbakır region. These included the carapace of a juvenile turtle that was hung from the entrance of a house in order to keep evil away from the family, and a tortoise carapace hung with the skull of a bull, a bottle of salt and some wheat from the roof of a building in Sürgücü/Mardin to ensure fertility in a new house. In the city of Tokat, tortoise carapaces are buried in fields to increase the richness of their soil (Kozbe \& Erdal in press).

\section{Conclusion}

The discovery of Euphrates soft-shelled turtles, a spur-thighed tortoise and Middle Eastern terrapins in a post-Assyrian grave at Kavuşan Höyük sheds new light on the use of these species in ancient Mesopotamian cultures. From the Neolithic onwards, chelonian species are only very rarely represented in Mesopotamian faunal assemblages. The symbolic, apotropaic and healing values of these animals were important, however, in Mesopotamian societies. Kavuşan Höyük, with its lack of chelonian remains beyond those recovered from the grave in silo 3, is emblematic of the striking disparity between the economic and symbolic value of the Euphrates soft-shelled turtle. This contrast is apparent elsewhere in the Near East for other species of tortoise, turtle and terrapin.

Among the various symbolic values attributed to chelonians, their role as psychopomps, responsible for escorting newly deceased souls to the afterlife, has been supported by several archaeological discoveries. The grave deposit at Kavuşan Höyük confirms that, despite their different habitats and behaviours, turtles, tortoises and terrapins living in Mesopotamia were all used in funerary rituals and played similar symbolic roles in different chronological and cultural contexts. The deposit also contains evidence of two different treatment processes for chelonians used in funerary practices. The Euphrates soft-shelled turtles were butchered and consumed during feasts, in a manner similar to that recorded for spur-thighed tortoises in the Epi-Palaeolithic of the southern Levant. Conversely, at Kavuşan Höyük, spur-thighed tortoises and Middle Eastern terrapins were only represented by their empty shells, and appear not to have been butchered for consumption. While the shells recall the role

(C) Antiquity Publications Ltd, 2016 
of the chelonians as psychopomps, these two species only played a passive role in this funerary ritual. Although their shells were cleaned and used, tortoises and terrapins were not specifically hunted and consumed in the way that turtles appear to have been. Burials from the post-Assyrian period remain poorly understood, but it is not probable that the ritual consumption and deposition of chelonians in graves was a common practice. The ritual evidenced at Kavuşan Höyük probably attests to the peculiar social status of the deceased. For many cultures, chelonians are symbols of eternal life, longevity, endurance, strength and intelligence; in south-eastern Turkey, it is still believed that they ward off death. The symbolic significance of these animals endures even to this day, 2600 years since the funerary ritual performed at Kavuşan Höyük.

\section{Acknowledgements}

We would like to thank S. Bailon (MNHN, Paris), M. Biricik (Dicle University, Diyarbakır), L. Gourichon (CNRS, Nice), E. Taşkavak (Ege University, Izmir), D. Ayaz (Ege University, Izmir) and Ş. Turğa (Dicle University, Diyarbakır) for sharing information and documentation related to turtles, tortoises and terrapins with us. The archaeological specimens of spur-thighed tortoise and Middle Eastern terrapin were kindly identified by S. Bailon in the reptile collections of comparative anatomy at the Muséum national d'Histoire naturelle in Paris. We owe our deepest thanks to the local people in Diyarbakır who participated in the ethnographic survey and answered our questions.

\section{References}

ACSÁDI, G. \& J. NEMESKÉRI. 1970. History of human life span and mortality. Budapest: Akadémiai Kiadó.

AINSWORTH, W.F. 1888. A personal narrative of the Euphrates expedition. London: K. Paul Trench.

Alster, B. 1972. Ninurta and the turtle, UET 6/1 2. Journal of Cuneiform Studies 24: 120-25. http://dx.doi.org/10.2307/1359631

BeCKER, C. 1991. Erste Ergebnisse zu den Tierknochen aus Tall Seh Hamad-Die Funde aus Raum A des Gebäudes P, in H. Kühne (ed.) Die rezente Umwelt von Tall Seh Hamad und Daten zur Umwelt rekonstruktion der Assyrischen Stadt Dur-Katlimmu (Berichte der Ausgrabung von Tall Seh Hamad/Dur-Katlimmu 1): 117-32. Berlin: D. Reimer.

- 2008. Die Tierknochenfunde aus Tall Seh Hamad/Dur-Katlimmu_eine zoogeographisch-haustierkundliche Studie, in H. Kühne (ed.) Umwelt und Subsistenz der assyrischen Stadt Dur-Katlimmu am unteren Habur (Berichte der Ausgrabung von Tall Seh Hamad/Dur-Katlimmu 8): 61-131. Wiesbaden: Harrassowitz.

Berthon, R. 2011. Animal exploitation in the Upper Tigris River Valley (Turkey) between the $3^{\text {rd }}$ and the $1^{\text {st }}$ millennia $B C$. $\mathrm{PhD}$ dissertation,

Christian-Albrechts-Universität zu Kiel. Available at: http://d-nb.info/1020244658/34 (accessed 28 October 2015).
- 2013. New data on the exploitation of animal resources in the Upper Tigris River area (Turkey) during the second and first millennia BC, in B. de Cupere, V. Linseele \& S. Hamilton-Dyer (ed.) Archaeozoology of the Near East X: Proceedings of the Tenth International Symposium on the Archaeozoology of South-Western Asia and Adjacent Areas (Ancient Near Eastern Studies Supplement 44): 145-62. Leuven, Paris \& Walpole: Peeters.

BIRICIK, M. \& Ş. TURĞA. 2011. Description of an Euphrates soft-shell turtle (Rafetus euphraticus) nest from the Tigris River (SE Turkey). Salamandra 47: 99-102.

BoessneCK, J. 1977. Sonstige Tierknochenfunde aus Isan Bahriyat (Isin), in B. Hrouda (ed.) Isin-Isan Bahriyat I: die Ergebnisse der Ausgrabungen 1973-1974 (Bayerische Akademie der Wissenschaften, Philosophisch-historische Klasse Abhandlungen Neue Folge 79): 111-33. München: Verlag der Bayerischen Akademie der Wissenschaften.

- 1978. Tierknochenfunde aus Nippur, in M. Gibson (ed.) Excavations at Nippur: twelfth season (Oriental Institute Communications 23): 153-87. Chicago (IL): The Oriental Institute.

- 1992a. Besprechung der Tierknochen- und Molluskenreste von Hassek Höyük, in M.R. Behm-Blancke (ed.) Hassek Höyük: naturwissenschaftliche Untersuchungen und lithische Industrie (Istanbuler Forschungen 38): 58-74. Tübingen: E. Wasmuth. 
- 1992b. Tierknochen aus Warqa, Iraq (Nachtrag), in M. van Ess \& F. Pedde (ed.) Uruk: Kleinfunde II (Ausgrabungen in Uruk-Warka 7): 267-70. Mainz am Rhein: P. von Zabern.

BOESSNECK, J. \& A. VON DEN DRIESCH. 1986. Tierknochen- und Molluskenfunde aus Munbâqa. Mitteilungen der Deutschen Orient-Gesellschaft zu Berlin 118: 147-60.

- 1989. Die Faunenreste vom Tell Halawa am Assad-See/Nordsyrien (Drittes und Anfangzweites Jahrtausend v. Chr.), in W. Orthmann (ed.) Halawa 1980-1986: Vorläufer Berichtüber die 4-9 Grabungskampagne (Saarbrücker Beiträge zur Altertumskunde 52): 113-52. Bonn: R. Habelt.

- 1992. Tierknochenfunde IV. Serie 1986 und 1988, in B. Hrouda (ed.) Isin-Isan Bahriyat IV: die Ergebnisse der Ausgrabungen 1986-1989 (Bayerische Akademie der Wissenschaften,

Philosophisch-historische Klasse Abhandlungen Neue Folge 105): 176-87. München: Verlag der Bayerischen Akademie der Wissenschaften.

BoessneCK, J. \& M. KOKABI. 1981. Tierknochenfunde II. Serie, in B. Hrouda (ed.) Isin-Isan Bahriyat II: die Ergebnisse der Ausgrabungen 1975-1978 (Bayerische Akademie der Wissenschaften, Philosophisch-historische Klasse Abhandlungen Neue Folge 87): 131-55. München: Verlag der Bayerischen Akademie der Wissenschaften.

BoessneCK, J. \& R. Ziegler. 1987. Tierknochenfunde III. Serie 1983-1984 (7-8 Kampagne), in B. Hrouda (ed.) Isin-Isan Bahriyat II: die Ergebnisse der Ausgrabungen 1983-1984 (Bayerische Akademie der Wissenschaften,

Philosophisch-historische Klasse Abhandlungen Neue Folge 94): 138-50. München: Verlag der Bayerischen Akademie der Wissenschaften.

BuIKSTRA, J.E. \& D.H. UBELAKER. 1994. Standards for data collection from human skeletal remains. Indianapolis (IN): Western Newspaper Company.

ÇAKIRlAR, C. 2009a. Aççana Höyüğü’nde arkeozooloji çalışmaları: 2007 yılı raporu. Arkeometri Sonuçları Toplantısı 24: 253-66.

- 2009b. Faunal remains from the 2003-2004 excavations at Tell Atchana, in K.A. Yener (ed.) Tell Atchana, Ancient Alalakh: 137-42. Istanbul: Ege Yayınları.

Corsini-FoKA, M. \& M. Masseti. 2008. On the oldest-known record of the Nile soft-shelled turtle, Trionyx triunguis (Forskall, 1775), in the eastern Aegean Islands (Greece). Zoology in the Middle East 43: 108-10. http://dx.doi.org/10.1080/ 09397140.2008.10638276

CoşKun, A., M. BenZ, Y.S. ERdal, M.M. KorUyucu, K. Deckers, S. Riehl, A. Siebert, K.W. Alt \& V. OZKAYA. 2010. Living by the water-boon and bane for the people of Körtik Tepe. Neo-Lithics 2: $60-71$.
VON DEN DRIESCH, A. 1993. Faunal remains from Habuba Kabira in Syria, in H. Buitenhuis \& A.T. Clason (ed.) Archaeozoology of the Near East: Proceedings of the First International Symposium on the Archaeozoology of South-western Asia and Adjacent Areas: 52-59. Leiden: Universal Book Services.

FritZ, U. \& P. HAVAš. 2007. Checklist of the chelonians of the world. Vertebrate Zoology 57: 149-368.

Ghaffari, H., E. TaşKaVAK \& M. Karami. 2008. Conservation status of the Euphrates soft-shelled turtle, Rafetus euphraticus, in Iran. Chelonian Conservation and Biology 7: 223-29. http://dx.doi.org/10.2744/CCB-0717.1

Gourichon, L. \& D. Helmer. 2003. Preliminary analysis of the faunal remains from Tell Kosak Shamali (Syria): squares AD5, AE5, AF5, BD6 and BE6, in Y. Nishiaki \& T. Matsutani (ed.) Tell Kosak Shamali: the archaeological investigations on the Upper Euphrates, Syria. Volume 2: Chalcolithic technology and subsistence (University Museum University of Tokyo Monographs 2): 273-82. Oxford: Oxbow Books.

Grosman, L., N.D. Munro \& A. Belfer-Cohen. 2008. A 12,000-year-old shaman burial from the southern Levant (Israel). Proceedings of the National Academy of Sciences of the USA 105: 17665-69. http://dx.doi.org/10.1073/pnas.0806030105

KINZELBACH, R. 1986. Recent records of the Nile soft-shelled turtle, Trionyx triunguis, and of the Euphrates soft-shelled turtle, Trionyx euphraticus, in the Middle East. Zoology in the Middle East 1: 83-87. http://dx.doi.org/10.1080/09397140.1986. 10637519

Kozbe, G. 2010. Kavuşan Höyük Kazısı, 2008. Kazı Sonuçları Toplantısı 31: 173-96.

- 2012. Kavuşan Höyük, in A. Çilingiroğlu, Z. Mercangöz \& G. Polat (ed.) Ege Universitesi Arkeoloji Kazıları: 293-314. Izmir: Ege Üniversitesi Kültür Yayınları.

- 2013. Excavations at Diyarbakır/Kavuşan Höyük, 2005-2008, in Kültür Varlıkları ve Müzeler Genel Müdürlügü-Diyarbakır Müze Müdürlüğ̈̈ (ed.) The Ilisu Dam and HEP Project Excavations Season 2004-2008: 346-76. Diyarbakır: Diyarbakır Müzesi Müdürlüğ̈̈-Arkeolojive Sanat Yayınları.

KOZBE, G. \& Y.S. ERDAL. In press. Diyarbakır-Kavuşan Höyük'ten Bir Gömünün Etnoarkeolojik Açıdan Analizi. Ulusal Biyolojik Antropoloji Sempozyumu Bildileri 5.

KRUPP, F. \& W. SCHNEIDER. 1991. Bestandserfassung der rezenten Fauna im Bereich des Nahr al-Habur, in H. Kühne (ed.) Die rezente Umwelt von Tall Seh Hamad und Daten zur Umweltrekonstruktion der Assyrischen Stadt Dur-Katlimmu (Berichte der Ausgrabung von Tall Seh Hamad/Dur-Katlimmu 1): 69-85. Berlin: D. Reimer.

(C) Antiquity Publications Ltd, 2016 
LAYARD, A.H. 1853. Discoveries in the ruins of Niniveh and Babylon: with travels in Armenia, Kurdistan and the desert: being the result of a second expedition undertaken for the trustees of the British Museum. London: J. Murray.

Méry, S. \& V. CHARPENTIER. 2009. Rites funéraires du Néolithique et de l'âge du Bronze ancien en Arabie orientale, in J. Guilaine (ed.) Sépultures et sociétés. Du Néolithique à l'Histoire: 10-40. Paris: Éditions Errance.

OliviER, G.A. 1807. Voyage dans l'Empire Othoman, l'Egypte et la Perse, fait par ordre du Gouvernement, pendant les six premières années de la République. Paris: H. Agasse.

OwEN, D.I. 1981. Of birds, eggs and turtles. Zeitschrift für Assyriologie 71: 29-47. http://dx.doi.org/10.1515/zava.1981.71.1.29

ÖZKaYA, V. \& A. CoşKUN. 2011. Körtik Tepe 2009 Yılı Kazısı. Kazı Sonuçları Toplantısı 32: 81-100.

PAYNE, S. 1988. Animal bones from Tell Rubeidheh, in R.G. Killick (ed.) Tell Rubeidheh: an Uruk village in the Jebel Hamrin (Iraq Archaeological Reports 2): 98-135. Warminster: Aris \& Phillips.

Peterson, J.L. 2007. A study of Sumerian faunal conception with a focus on the terms pertaining to the order Testudines. Unpublished PhD dissertation, University of Pennsylvania.

ReIner, E. \& M.T. RoTH (ed.). 1999. The Assyrian dictionary of the Oriental Institute of the University of Chicago, Volume 14: R. Chicago (IL): The Oriental Institute.

Salvatori, S. 1996. Death and ritual in a population of coastal food foragers in Oman, in E. Afanas'ev, S. Cleuziou, J.R. Lukacs \& M. Tosi (ed.) Prehistory of Asia and Oceania (XIII International Congress of Prehistoric and Protohistoric Sciences 16): 205-22. Forlí: Abaco.

STADTLANDER, T. 1992. Recent observations of the Euphrates soft-shelled Turtle, Rafetus euphraticus, in Mesopotamia. Zoology in the Middle East 7: 55-58. http://dx.doi.org/10.1080/09397140.1992. 10637624
STAHL, U. 1989. Tierknochenfunde vom Hassek Höyük. Unpublished PhD dissertation, Ludwig-Maximilians-Universität München.

Starkovich, B.M. \& M.C. STINer. 2009. Hallan Çemi Tepesi: high-ranked game exploitation alongside intensive seed processing at the Epipaleolithic-Neolithic transition in south-eastern Turkey. Anthropozoologica 44: 41-61. http://dx.doi.org/10.5252/az2009n1a2

Stiner, M.C., N.D. Munro \& T.A. Surovell. 2000. The tortoise and the hare. Small-game use, the broad-spectrum revolution, and paleolithic demography. Current Anthropology 41: 39-73. http://dx.doi.org/10.1086/300102

Stiner, M.C., H. Buitenhuis, G. Duru, S.L. KuHN, S.M. Mentzer, N.D. Munro, N. PÖllath, J. Quade, G. TSARTSIDOU \& M. OZbaşARAN. 2014. A forager-herder trade-off, from broad-spectrum hunting to sheep management at Aşıklı Höyük, Turkey. Proceedings of the National Academy of Sciences of the USA 111: 8404-409.

TAŞKAVAK, E. 1998. Comparative morphology of the Euphrates soft-shelled turtle, Rafetus euphraticus, (Daudin, 1802) (Reptilia, Testudines) in south-eastern Anatolia. Amphibia-Reptilia 19: 281-91. http://dx.doi.org/10.1163/ 156853898 X00188

TaŞKAVAK, E. \& M.K. ATATÜr. 1998. Distribution and habitats of the Euphrates soft-shelled turtle, Rafetus euphraticus, in south-eastern Anatolia, Turkey, with observations on biology and factors endangering its survival. Chelonian Conservation and Biology 3: 20-30.

Vamberger, M., H. Stuckas, D. Ayaz, E. Graciá, A.A. Aloufi, J. Els, L.F. Mazanaeva, H. Gholi KAMI \& U. FrITZ. 2013. Conservation genetics and phylogeography of the poorly known Middle Eastern terrapin Mauremys caspica (Testudines: Geoemydidae). Organisms Diversity \& Evolution 13: 77-85. http://dx.doi.org/10.1007/ s13127-012-0102-6

WeSZELI, M. 2009. Schildkröte. Reallexikon der Assyriologie 12: 179-82.

Received: 5 December 2014; Accepted: 26 February 2015; Revised: 8 March 2015

(C) Antiquity Publications Ltd, 2016 